\title{
NADPH oxidase-derived free radicals are key oxidants in alcohol-induced liver disease
}

\author{
Hiroshi Kono, ${ }^{1}$ Ivan Rusyn, ${ }^{1,2}$ Ming Yin, ${ }^{1}$ Erwin Gäbele, ${ }^{1}$ Shunhei Yamashina,,${ }^{1}$ \\ Anna Dikalova, ${ }^{3}$ Maria B. Kadiiska, ${ }^{3}$ Henry D. Connor, ${ }^{3}$ Ronald P. Mason, ${ }^{2,3}$ \\ Brahm H. Segal, ${ }^{4}$ Blair U. Bradford, ${ }^{1}$ Steven M. Holland, ${ }^{4}$ and Ronald G. Thurman ${ }^{1,2}$ \\ ${ }^{1}$ Laboratory of Hepatobiology and Toxicology, Department of Pharmacology, and \\ ${ }^{2}$ Curriculum in Toxicology, University of North Carolina, Chapel Hill, North Carolina, USA \\ ${ }^{3}$ Laboratory of Pharmacology and Chemistry, National Institute of Environmental Health Sciences, NIH, \\ Research Triangle Park, North Carolina, USA \\ ${ }^{4}$ Laboratory of Host Defenses, National Institute of Allergy and Infectious Diseases, NIH, Bethesda, Maryland, USA
}

Address correspondence to: Ivan Rusyn, Laboratory of Hepatobiology and Toxicology, Department of Pharmacology, CB\#7365, Mary Ellen Jones Building, University of North Carolina at Chapel Hill, Chapel Hill, North Carolina 27599-7365, USA. Phone: (919) 966-1154; Fax: (919) 966-1893; E-mail: iir@med.unc.edu.

Received for publication January 18, 2000, and accepted in revised form August 30, 2000.

In North America, liver disease due to alcohol consumption is an important cause of death in adults, although its pathogenesis remains obscure. Despite the fact that resident hepatic macrophages are known to contribute to early alcohol-induced liver injury via oxidative stress, the exact source of free radicals has remained a mystery. To test the hypothesis that NADPH oxidase is the major source of oxidants due to ethanol, we used $\mathrm{p}^{4} 7^{\text {phox }}$ knockout mice, which lack a critical subunit of this major source of reactive oxygen species in activated phagocytes. Mice were treated with ethanol chronically, using a Tsukamoto-French protocol, for 4 weeks. In wild-type mice, ethanol caused severe liver injury via a mechanism involving gut-derived endotoxin, CD14 receptor, production of electron spin resonance-detectable free radicals, activation of the transcription factor NF- $\mathrm{KB}$, and release of cytotoxic TNF- $\alpha$ from activated Kupffer cells. In NADPH oxidase-deficient mice, neither an increase in free radical production, activation of NF- $\kappa B$, an increase in TNF- $\alpha$ mRNA, nor liver pathology was observed. These data strongly support the hypothesis that free radicals from NADPH oxidase in hepatic Kupffer cells play a predominant role in the pathogenesis of early alcohol-induced hepatitis by activating NF- $\kappa B$, which activates production of cytotoxic TNF- $\alpha$.

J. Clin. Invest. 106:867-872 (2000).

\section{Introduction}

Alcohol is the third leading cause of preventable mortality in the US and contributes to about 100,000 deaths annually. The economic burden of alcoholism on the US economy, in great part due to health care expenditures, rose $42 \%$ to $\$ 148$ billion from 1985 to $1992(1,2)$. Despite the fact that the population in general is well aware of the adverse and often fatal consequences of alcohol consumption, it is estimated that more than $7 \%$ of individuals 18 and over have problems with drinking. Alcoholic liver disease is one of the major drinking-related health problems and a primary cause of liver disease among Caucasians.

Histopathological features of alcoholic liver disease include fat accumulation and hepatitis, followed by fibrosis and cirrhosis. A major breakthrough in understanding the molecular mechanisms of these pathological changes was the development of an enteral animal model of alcoholic liver disease in the rat by Tsukamoto et al. (3). In the rat liver, when ethanol-containing diet is delivered continuously, pathological changes reflective of human alcoholic liver disease occur (i.e., fat accumulation, inflammation, and fibrosis). One hypothesis to account for the mechanism of alcoholinduced liver injury is that CYP2E1, induced predominantly in hepatocytes by ethanol, increases production of free radicals. Indeed, ethanol causes formation of $\alpha$ hydroxyethyl radical in the Tsukamoto-French rat model (4); however, CYP2E1 is most likely not involved in this process, as no differences in liver injury and free radical formation were observed when wild-type and CYP2E1 knockout mice were compared $(5,6)$.

On the other hand, evidence has been presented in support of the hypothesis that Kupffer cells, the resident hepatic macrophages, play a key role in alcoholinduced liver damage $(7,8)$. Specifically, it is known that alcohol increases gut permeability for Gram-negative bacterial endotoxin. Endotoxin is a potent activator of Kupffer cells, which release toxic cytokines and inflammatory mediators (e.g., TNF- $\alpha$ ) as well as reactive oxygen species. Indeed, Kupffer cells may be the source of oxidants (9). NADPH oxidase is a major oxidant-generating enzyme in activated macrophages (10). Here, therefore, we have adapted the enteral alcohol feeding model to the mouse (11) so that knockout technology can be used to test the hypothesis that oxi- 
Table 1

Effect of chronic enteral ethanol administration on routine parameters and pathology scores in wild-type and $\mathrm{p} 47$ phox-/- mice

\begin{tabular}{|c|c|c|c|c|}
\hline & \multicolumn{2}{|c|}{ Wild-type } & \multicolumn{2}{|c|}{ p47phox-/- } \\
\hline & $\begin{array}{l}\text { High-fat } \\
\text { control }\end{array}$ & $\begin{array}{l}\text { High-fat } \\
\text { ethanol }\end{array}$ & $\begin{array}{l}\text { High-fat } \\
\text { control }\end{array}$ & $\begin{array}{l}\text { High-fat } \\
\text { ethanol }\end{array}$ \\
\hline Weight gain (g/d) & $0.18 \pm 0.03$ & $0.17 \pm 0.04$ & $0.19 \pm 0.02$ & $0.18 \pm 0.03$ \\
\hline $\begin{array}{l}\text { Mean urine alcohol } \\
\text { concentration }(\mathrm{mg} / \mathrm{dl})\end{array}$ & NA & $248 \pm 17$ & NA & $255 \pm 22$ \\
\hline Liver/body weight ratio (\%) & $5.2 \pm 0.2$ & $8.2 \pm 0.3^{\mathrm{A}}$ & $5.1 \pm 0.3$ & $5.3 \pm 0.3^{B}$ \\
\hline Serum ALT $(U / I)$ & $30 \pm 3$ & $112 \pm 13^{A}$ & $28 \pm 8$ & $45 \pm 9^{B}$ \\
\hline Steatosis & 0 & $3.2 \pm 0.2^{C}$ & 0 & $0.3 \pm 0.1^{\mathrm{D}}$ \\
\hline Inflammation & 0 & $1.3 \pm 0.2^{\mathrm{C}}$ & $0.3 \pm 0.1$ & $0.4 \pm 0.1^{\mathrm{D}}$ \\
\hline Necrosis & 0 & $0.9 \pm 0.1^{\mathrm{C}}$ & 0 & $0.3 \pm 0.1^{\mathrm{D}}$ \\
\hline Total pathology score & 0 & $5.4 \pm 0.4^{C}$ & $0.3 \pm 0.1$ & $0.6 \pm 0.1^{\mathrm{D}}$ \\
\hline
\end{tabular}

Urine alcohol concentrations and serum ALT levels were determined as described in Methods. ${ }^{A} P<0.05$ compared with the wild-type control group, ${ }^{\mathrm{B}} \mathrm{P}<0.05$ compared with the wild-type ethanol group by two-way ANOVA using Bonferroni's post-hoc test. Pathological changes were scored as described in Methods. ${ }^{C} P<0.05$ compared with the wild-type control group, ${ }^{D} P<0.05$ compared with the wild-type ethanol group by the Mann-Whitney rank sum test.

dants from NADPH oxidase are involved in early alcohol-induced liver injury. This hypothesis was evaluated by comparing wild-type and NADPH oxidase-deficient (p47phox knockout [-/-]) mice (12) treated continuously with ethanol.

\section{Methods}

Animals and treatments. NADPH oxidase-deficient (p47phox-/-) mice lack a critical cytosolic component required for assembly of an active NADPH oxidase complex (12). The animals were the product of embryonic stem cell 129/Sv-derived sperm and C57BL/6derived eggs. The product of this mating was bred back onto a control inbred laboratory C57BL/6 strain three times. Heterozygotes were crossed to yield homozygote knockouts and wild types. From this progeny, the knockout and wild-type lines were expanded in parallel. Mice were housed in a pathogen-free barrier facility accredited by the Association for the Accreditation and Assessment of Laboratory Animal Care, and procedures were approved by the University of North Carolina Institutional Animal Care and Use Committee. Two-month-old female mice (18-20 g initial body weight) were used, and gastric cannulation was performed utilizing aseptic surgical techniques as detailed elsewhere (11). Mice were placed in individual sterile metabolic cages, and the end of the gastric cannula was connected to a swivel and infusion pump. All mice were maintained in a sterile facility and had free access to water and cellulose pellets as a source of fiber (Harlan Teklad, Madison, Wisconsin, USA). A liquid diet described by Thompson and Reitz (13), supplemented with lipotropes as detailed by Morimoto et al. (14), was prepared daily. Either ethanol (35-40\% of total calories) or isocaloric maltose-dextrin (control diet) was added as described elsewhere (15). Mice were randomly divided into two experimental groups and fed either highfat control or ethanol-containing diet continuously for up to 4 weeks via an intragastric cannula. The diet $(1.29-1.31 \mathrm{kcal} / \mathrm{ml})$ was infused at a rate of $0.44 \mathrm{ml} / \mathrm{g}$ body weight per day with an infusion pump (Edco Scientific, Chapel Hill, North Carolina, USA). The degree of alcohol intoxication was assessed to evaluate development of tolerance so that ethanol delivery could be increased. The amount of ethanol in the diet was varied from $4-8 \%$ to obtain optimal delivery of calories without compromising growth or survival. The initial rate of ethanol delivery (14 g/kg per day, $27 \%$ of total calories) was increased $1 \mathrm{~g} / \mathrm{kg}$ per 2 days until the end of the first week and then $1 \mathrm{~g} / \mathrm{kg}$ per 4 days until the end of the experiment (final rate $28 \mathrm{~g} / \mathrm{kg}$ per day, $38 \%$ of total calories). Ethanol concentrations in urine and transaminases in serum were measured (16). Livers were fixed in formalin, embedded in paraffin, and stained with hematoxylin and eosin (H\&E) to assess steatosis, inflammation, and necrosis. Pathology was scored in a blinded manner (17). The utility of this model for mechanistic studies using knockout mice is clear; however, differences in transaminase release and inflammation indicate that this model is not identical with human alcoholic hepatitis.

Knockout mice that have been backcrossed less than 4 times will differ genetically from the wild-type strain not only at the locus of interest, but at other loci as well (18). To partially address this possibility, we compared total pathology scores following enteral alcohol in our p47phox wild-type strain with pure C57BL/6 mice. Indeed, total pathology scores in pure C57BL/6 mice $(5.5 \pm 0.6)$ and the 447 phox wild-type strain $(5.4 \pm 0.4)$ were not significantly different $(P=0.814)$, which provides evidence that the response of the p47phox wildtype strain to alcohol was not different from that exhibited by pure C57BL/6 animals. However, these two control strains may differ from the $447^{\text {phox }}$ knockout strain at loci other than $\mathrm{p} 47$ phox (reviewed in ref. 18), thus leaving open the formal possibility that the protection from alcohol-induced liver injury observed in the $\mathrm{p} 47^{\text {phox }}$ null strain may be determined by genetic differences in loci that are distinct from, or interact with, the $\mathrm{p} 47 \mathrm{phox}$ locus.

Collection of bile and detection of free radical adducts. Ethanol concentration in the breath was analyzed by gas chromatography to verify that animals in different groups had similar blood alcohol levels (200-250 $\mathrm{mg} / \mathrm{dl}$ ) when comparisons were made. Mice were anesthetized with pentobarbital $(75 \mathrm{mg} / \mathrm{kg})$, the abdomen was opened, and the gallbladder was cannulated. After 
the spin trap POBN $(1 \mathrm{~g} / \mathrm{kg})$ was administered intraperitoneally, bile samples $(200-300 \mu \mathrm{l})$ were collected for 3 hours into $35 \mu \mathrm{l}$ of $0.5 \mathrm{mM}$ deferoxamine mesylate to prevent ex vivo radical formation. During bile collection, $0.1 \mathrm{ml}$ of saline was injected intravenously at 30-minute intervals to prevent dehydration. Samples were stored at $-80^{\circ} \mathrm{C}$ until analyzed by ESR spectroscopy (4). ESR spectra were obtained using a Bruker EMX ESR spectrometer (Bruker Instruments Inc., Billerica, Massachusetts, USA). The instrument settings were $20-\mathrm{mW}$ microwave power, $1.0-\mathrm{G}$ modulation amplitude, 80-G scan width, 16-minute scan, and 1-second time constant. Simulations of radical spectra were performed as detailed elsewhere (19).

Preparation of nuclear extracts and electrophoretic mobility shift assays. Nuclear protein extracts were prepared on ice as described by Dignam et al. (20) with minor modifications (21). Protein concentration was determined using the Bradford protein concentration assay kit (Bio-Rad Laboratories Inc., Hercules, California, USA) (22). A gel mobility shift assay was used to assess the amount of active protein involved in protein-DNA interactions (23). The specificity of protein binding in nuclear extracts was confirmed in competition and supershift experiments. Labeled and unlabeled oligonucleotides contained the consensus sequence for NF-KB (24). Data were quantitated by scanning autoradiograms with GelScan XL (Amersham Pharmacia Biotech Ltd., Uppsala, Sweden).

Isolation of RNA and RNase protection assays. RNA was extracted from samples of liver tissue using QuickPrep Total RNA Extraction Kit (Amersham Pharmacia Biotech, Piscataway, New Jersey, USA). TNF- $\alpha$, IL-
6, and the housekeeping gene GAPDH were detected with a mouse cytokine RNA probe template set (mCK3b; PharMingen, San Diego, California, USA). Riboprobes were synthesized in the presence of $\left[{ }^{32} \mathrm{P}\right] \mathrm{UTP}$ to yield labeled antisense RNA probes, and RNase protection assays were performed on $30 \mu \mathrm{g}$ of liver RNA samples using a RiboQuant multiprobe RNase Protection Assay Kit (PharMingen). Protected fragments were separated on $6 \%$ polyacrylamide QuickPoint gels (Novex, San Diego, California, USA), dried, and exposed to $\mathrm{x}$-ray film.

Statistics. Results are reported as means \pm SEM with $n=4$ to 5 in each group. One- or two-way ANOVA and Student-Neuman-Keuls post-hoc test were used where appropriate. $P<0.05$ was selected prior to the study to determine statistical differences between groups.

\section{Results and Discussion}

Alcohol-containing or control diets were initiated 1 week after surgery to allow for complete recovery, and all mice were healthy during the enteral feeding period. No differences in behavior between wild-type and p47phox-/- mice fed ethanol were observed. Mice gained weight steadily during 4 weeks of continuous enteral feeding of liquid diets with or without ethanol, indicating adequate nutrition (see Table 1). In both rats and mice, urine alcohol levels fluctuated in a cyclic pattern even though ethanol was infused continuously $(3,11)$. Recently, it was reported that the cyclic oscillation of the urinary alcohol level in rats fed ethanol involves fluctuation of body temperature and thyroid hormone release (25). Since similar patterns were observed here in p47 phox-/- mice, it is concluded that NADPH oxidase is
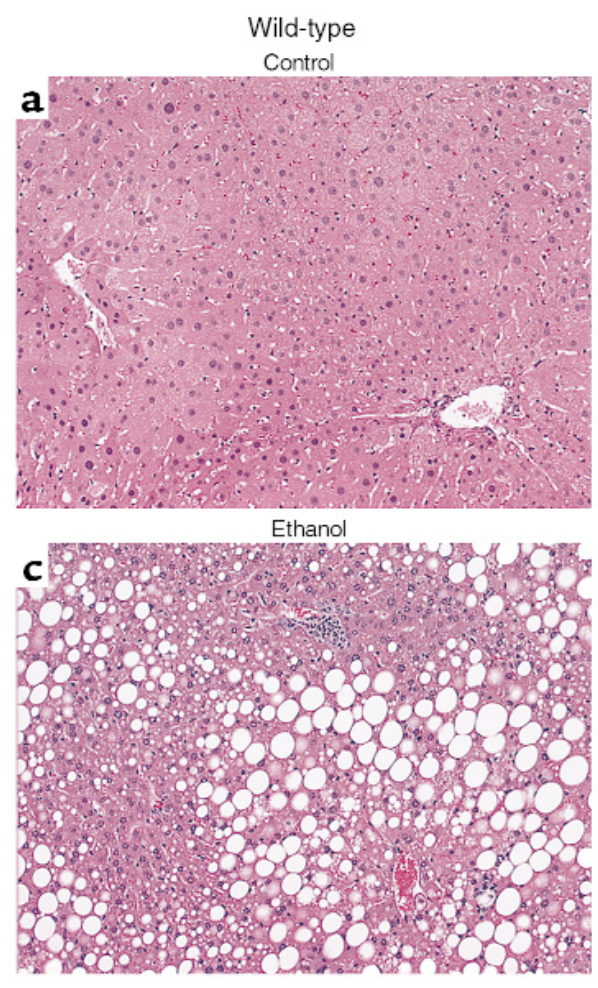

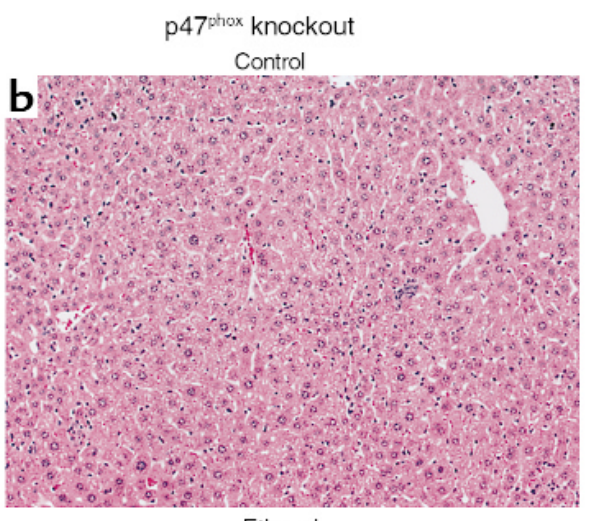

Ethanol

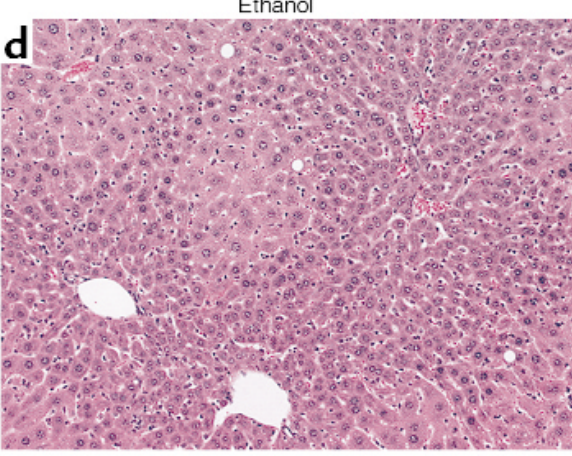

\section{Figure 1}

Histopathological signs of alcoholic liver injury: steatosis, inflammation and necrosis are evident in liver of wildtype but not NADPH oxidase-deficient mice after 4 weeks of enteral ethanol treatment. Wild-type (a and $\mathbf{c}$ ) and p47phox-/- (b and $\mathbf{d})$ mice were given high-fat (control; $\mathbf{a}$ and $\mathbf{b}$ ) or ethanolcontaining (c and $\mathbf{d}$ ) diets via an intragastric cannula for 4 weeks. Liver samples were harvested and stained with H\&E. Representative photomicrographs; original magnification, $\times 100$. 
a

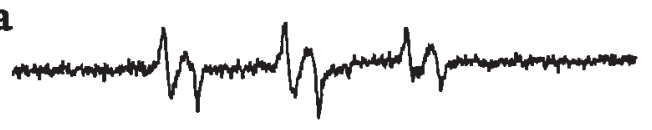

b
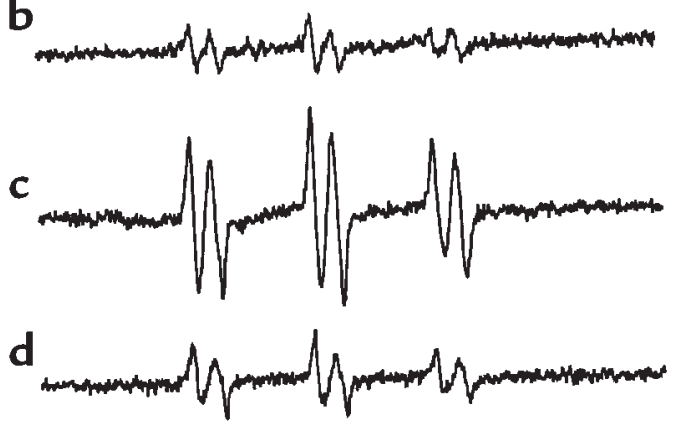

20 Gauss

Figure 2

Formation of ESR-detectable free radical adducts due to ethanol administration is blocked in NADPH oxidase-deficient mice. Wildtype mice and $\mathrm{p} 47 \mathrm{phox}$, respectively, were fed enteral high-fat control $\operatorname{diet}(\mathbf{a}, \mathbf{b})$ or enteral high-fat ethanol-containing $\operatorname{diet}(\mathbf{c}, \mathbf{d})$ for 4 weeks. After POBN injection ( $1 \mathrm{~g} / \mathrm{kg}$ intraperitoneally), bile was collected and analyzed using ESR spectroscopy. Representative ESR spectra of seven separate experiments are shown.

not involved. Average urine alcohol concentrations over 4 weeks were $248 \pm 17 \mathrm{mg} / \mathrm{dl}$ (mean \pm SEM) in wild-type and $255 \pm 22 \mathrm{mg} / \mathrm{dl}$ in p47phox-/- mice (see Table 1). Serum ALT levels were about $30 \mathrm{U} / 1$ in wild-type mice fed a high-fat control diet for 4 weeks; however, values were increased significantly, about threefold, by enteral ethanol (see Table 1). In contrast, increases were blocked completely in p47phox- $/$ - mice fed ethanol.

After 4 weeks of the high-fat control diet, there were no pathological changes in the livers of wild-type mice (Figure 1a) or unexpected changes in $\mathrm{p} 47 \mathrm{phox}-/-$ mice fed a high-fat diet (Figure 1b) (12). Wild-type mice fed enteral ethanol developed severe steatosis in pericentral to midzonal regions, as well as inflammation and necrosis (Figure 1c), with a total pathology score of 5.4 \pm 0.4 (see Table 1). A macro- or microvesicular pattern of fat accumulation was observed mainly in pericentral to midzonal regions, except for 1 to 3 layers of hepatocytes around central veins. In contrast, these pathological changes were prevented nearly completely in p47phox-/- mice fed enteral ethanol (Figure 1d) (total pathology score, $0.6 \pm 0.1$ ).

Free radical adducts were barely detectable in bile from wild-type mice (Figure $2 \mathrm{a}$ ) and $\mathrm{p} 47 \mathrm{phox}-{ }_{-}$mice (Figure $2 \mathrm{~b}$ ) using the spin trapping technique and ESR. In contrast, 4 weeks of enteral ethanol caused formation of radical adducts in wild-type mice (Figure 2c). Spectral simulation revealed the presence of two spectra with hyperfine coupling constants: (I) $a^{\mathrm{N}}=15.8$ $\pm 0.2 \mathrm{G}$ and $a_{\beta}{ }^{\mathrm{H}}=2.5 \pm 0.2 \mathrm{G}$; and (II) $a^{\mathrm{N}}=15.6 \pm 0.2 \mathrm{G}$ and $a_{\beta}{ }^{H}=3.2 \pm 0.2 \mathrm{G}$. Spectrum I, which comprises $80 \%$ of the spectral intensity, is most likely derived from an

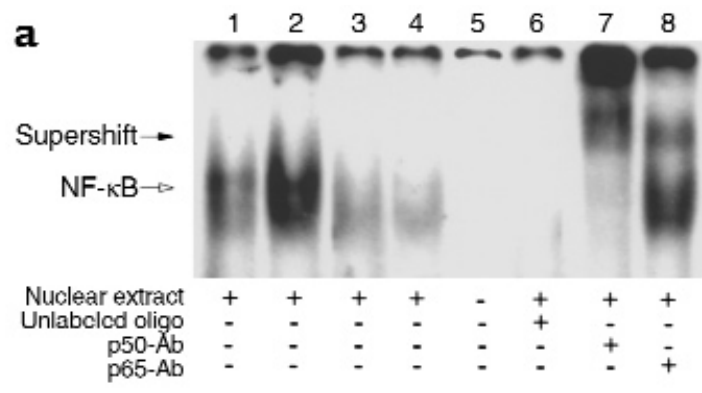

b

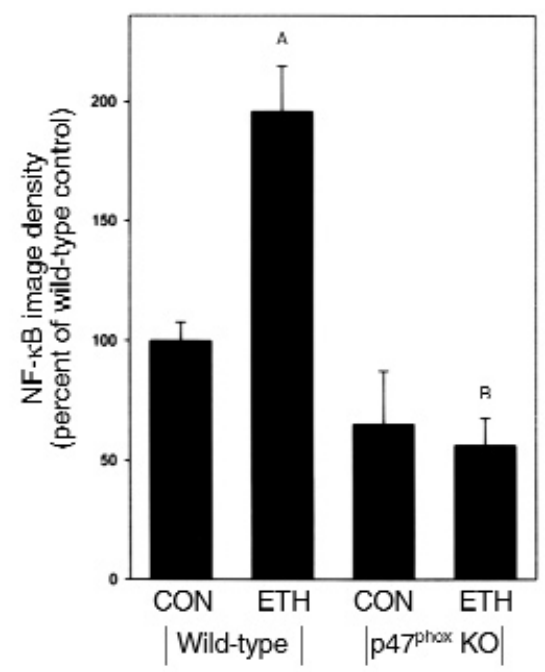

C

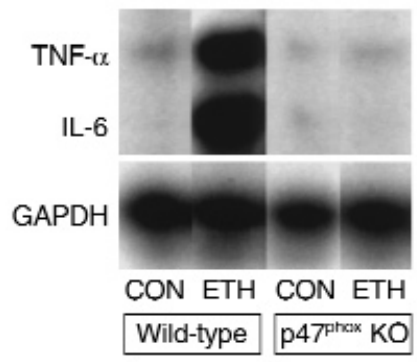

Figure 3

Ethanol administration activates the transcription factor NF- $\mathrm{\kappa B}$ and increases expression of mRNA for the inflammatory cytokines TNF- $\alpha$ and IL-6 in wild-type but not NADPH oxidase-deficient mice. (a) NFKB DNA binding activity in the liver was assessed by electrophoretic mobility shift assay using whole liver nuclear extracts from wild-type mice fed high-fat control (lane 1) or ethanol-containing (lane 2) diet, or 447 phox- $/$ - mice fed high-fat control (lane 3 ) or ethanol-containing (lane 4) diet. No binding was detected with no nuclear extract added (lane 5). Nuclear extracts from wild-type mice fed ethanol-containing diet (same as in lane 2) were used for competition experiments (200fold excess of the unlabeled oligonucleotide, lane 6) and supershift experiments (p50 or p65 anti-serum, lanes 7 and 8, respectively). Representative data from four separate experiments are shown. (b) Data shown are results of densitometric analysis of the NF-KB/DNA complex images. Density of the NF-KB/DNA complex image in livers from wild-type mice fed high-fat control diet was set to $100 \%$. Data represent mean $\pm \operatorname{SEM}(n=4)$. CON, high-fat control diet; ETH, high-fat ethanol-containing diet. ${ }^{A} P<0.05$ compared with wild-type mice fed high-fat control diet, ${ }^{B} P<0.05$ compared with wild-type mice fed ethanol-containing diet by two-way ANOVA with Bonferroni's posthoc test. (c) Total mRNA was prepared from livers of wild-type or p47phox-/- mice administered high-fat (CON) or ethanol-containing $(\mathrm{ETH})$ diets for 4 weeks, and RNase protection assays were performed. Representative data from four separate experiments are shown. 
approximately 50/50 mixture of $\alpha$-hydroxyethyl and lipid-derived free radical adducts $(4,26)$. ESR studies of such systems using ${ }^{13} \mathrm{C}$-ethanol have demonstrated the similarity of the hyperfine coupling constants and the presence of both radical adducts following chronic ethanol administration using Tsukamoto-French protocol (4). Spectrum II, with its unique $\beta$ hydrogen hyperfine coupling of $3.2 \mathrm{G}$, is most likely the $\mathrm{POBN} / \mathrm{CO}_{2}{ }^{-}$free radical adduct formed by the abstraction of a hydrogen atom from endogenous formate to give $\mathrm{CO}_{2}{ }^{-}$, which then reacts with $\mathrm{POBN}$ (27). Importantly, all three above-mentioned free radical adducts are formed from attacks of oxidants on the respective parent molecule.

On the other hand, radical adduct formation was not increased in $\mathrm{p} 47_{\mathrm{phox}-/-}$ mice fed ethanol (Figure 2d; $P<0.05)$. Endotoxin-activated Kupffer cells and infiltrating neutrophils are two possible sources of oxidant production. However, several sets of evidence point to the NADPH oxidase in Kupffer cells as a likely source of free radicals due to alcohol treatment. First, it was shown that inactivation of Kupffer cells with $\mathrm{GdCl}_{3}$ blocks formation of the $\alpha$-hydroxyethyl radical in the chronic enteral ethanol feeding model in rats (4). Furthermore, the number of infiltrating neutrophils does not increase until 2-4 weeks of enteral alcohol feeding, and liver injury is prevented early in $\mathrm{p} 47 \mathrm{phox}-1-$ mice when few neutrophils are present (data not shown). Furthermore, it was shown that acute ethanol treatment activates NADPH oxidase in rat Kupffer cells (28). Indeed, ethanol activates LPSstimulated superoxide production in Kupffer cells determined by SOD-inhibitable reduction of cytochrome c (29). In Kupffer cells isolated by standard procedures (30) from wild-type mice, superoxide was increased from $1.5 \pm 0.2 \mathrm{nmol} / 10^{6}$ cells per 15 minutes to $3.2 \pm 0.3$ by acute ethanol treatment $(5$ $\mathrm{g} / \mathrm{kg}$, intragastrically for 21 hours). However, LPS did not increase superoxide production in cells from p47phox-/- mice (control: $0.3 \pm 0.2 \mathrm{nmol} / 10^{6}$ cells per 30 minutes; LPS [10 $\mu \mathrm{g} / \mathrm{ml}]: 0.3 \pm 0.1)$. Furthermore, the radical scavenger allopurinol blocks alcoholinduced liver injury in the rat (31).

Oxidants can function not only as toxic substances, but also as second messengers $(32,33)$. For instance, the transcription factor NF- $\kappa \mathrm{B}$ is redox-sensitive and plays an important role in signaling (34). Since both alcohol and the peroxisome proliferator WY-14,643 activate NF- $\kappa B$ nearly exclusively in Kupffer cells in the rat (35), it was hypothesized that NF- $\mathrm{KB}$ is involved in alcohol-induced liver injury by stimulating TNF- $\alpha$ production in Kupffer cells. In wild-type mice fed a highfat control diet for 4 weeks, NF-KB activity was minimal; however, activity was increased significantly, about twofold, by enteral ethanol in wild-type mice (Figure 3, $\mathrm{a}$ and $\mathrm{b}$ ). In contrast, this increase was blocked completely in $\mathrm{p} 47 \mathrm{phox}-1-$ mice. Thus, the key transcription factor NF- $\mathrm{KB}$ is not activated by alcohol in NADPH oxidase-deficient mice.
Binding sites for NF- $\mathrm{BB}$ have been identified within the regulatory elements of genes for proinflammatory cytokines such as TNF- $\alpha$ (36). Recent evidence from this laboratory supports the hypothesis that TNF- $\alpha$ plays an essential role in early alcohol-induced liver injury. Specifically, anti-TNF- $\alpha$ serum reduces inflammatory cell infiltration and necrosis in the rat enteral alcohol model (37). Furthermore, alcoholinduced liver injury is present in wild-type mice fed enteral ethanol chronically, but not in TNF receptor-1 knockout mice (11). In this study, expression of TNF$\alpha$ and IL- 6 mRNA was increased in wild-type but not in $\mathrm{p} 47 \mathrm{phox}-/-$ mice fed ethanol-containing diet (Figure $3 c)$. TNF- $\alpha$ stimulates sinusoidal endothelial cells to synthesize adhesion molecules (e.g., ICAM-1 and others) that are involved in inflammation (38-40). Further, liver injury in wild-type mice fed enteral ethanol was prevented in ICAM-1 knockout mice (Kono et al., unpublished observations). TNF- $\alpha$ is also implicated in hepatic steatosis caused by ethanol (41). In this study, hepatic steatosis observed in wild-type mice was prevented nearly completely in $\mathrm{p}^{4} 7^{\mathrm{phox}-/-}$ mice (Figure 1 ), suggesting that TNF- $\alpha$ production enhanced by oxidants is involved in fat mobilization and/or metabolism during alcohol feeding.

Collectively, the data presented here are consistent with the following sequence of events: ethanol, endotoxin, Kupffer cell CD14, NADPH oxidase, oxidants, NF- $\kappa \mathrm{B}, \mathrm{TNF}$, cytotoxicity. Taken together, these results strongly support the hypothesis that oxidants from NADPH oxidase, most likely of Kupffer cell origin, play a key role in the pathogenesis of early alcoholinduced liver injury.

\section{Acknowledgments}

We thank N.R. Rice (National Cancer Institute) for a kind gift of anti-p50 and -p65 serum. This work was supported by grants from the National Institute on Alcohol Abuse and Alcoholism.

\footnotetext{
1. McGinnis, J.M., and Foege, W.H. 1993. Actual causes of death in the United States. JAMA. 270:2207-2212.

2.1998. The economic costs of alcohol and drug abuse in the United States: 1992. National Institute on Alcohol Abuse and Alcoholism/National Institute on Drug Abuse News Release. NIH.

3. Tsukamoto, H., Reiderberger, R.D., French, S.W., and Largman, C. 1984. Long-term cannulation model for blood sampling and intragastric infusion in the rat. Am. J. Physiol. 247:R595-R599.

4. Knecht, K.T., et al. 1995. Free radical adducts in the bile of rats treated chronically with intragastric alcohol: inhibition by destruction of Kupffer cells. Mol. Pharmacol. 47:1028-1034.

5. Koop, D.R., Klopfenstein, B., Iimuro, Y., and Thurman, R.G. 1997. Gadolinium chloride blocks alcohol-dependent liver toxicity in rats treated chronically with intragastric alcohol despite the induction of CYP2E1. Mol. Pharmacol. 51:944-950.

6. Kono, H., et al. 1999. CYP2E1 is not involved in early alcohol-induced liver injury. Am. J. Physiol. 277:G1259-G1267.

7. Nolan, J.P., Leibowitz, A., and Vladatin, A.L. 1980. Influence of alcohol on Kupffer cell function and possible significance in liver injury. In The reticuloendothelial system and pathogenesis of liver disease. $\mathrm{H}$. Liehr and $\mathrm{M}$. Green, editors. Elsevier Science. Amsterdam, The Netherlands. 125-136.

8. Thurman, R.G. 1998. Mechanisms of hepatic toxicity. II. Alcoholic liver injury involves activation of Kupffer cells by endotoxin. Am. J. Physiol. 275:G605-G611.

9. Adachi, Y., Bradford, B.U., Gao, W., Bojes, H.K., and Thurman, R.G. 1994. Inactivation of Kupffer cells prevents early alcohol-induced liver injury.
} 
Hepatology. 20:453-460.

10. Badwey, J.A., and Karnovsky, M.L. 1980. Active oxygen species and the function of phagocytic leukocytes. Annu. Rev. Biochem. 49:695-726.

11. Yin, M., et al. 1999. Essential role of TNF $\alpha$ in alcohol-induced liver injury. Gastroenterology. 117:942-952.

12. Jackson, S.H., Gallin, J.I., and Holland, S.M. 1995. The p47phox mouse knock-out model of chronic granulomatous disease. J. Exp. Med. 182:751-758.

13. Thompson, J.A., and Reitz, R.C. 1978. Effects of ethanol ingestion and dietary fat levels on mitochondrial lipids in male and female rats. Lipids. 13:540-550.

14. Morimoto, M., Zern, M.A., Hagbjork, A.L., Ingelman-Sundberg, M., and French, S.W. 1994. Fish oil, alcohol, and liver pathology: role of cytochrome P4502E1. Proc. Soc. Exp. Biol. Med. 207:197-205.

15. Tsukamoto, H., Gaal, K., and French, S.W. 1990. Insights into the pathogenesis of alcoholic liver necrosis and fibrosis: status report. Hepatology. 12:599-608.

16. Bergmeyer, H.U. 1963. Methods of enzymatic analysis. Academic Press. New York, New York, USA/London, United Kingdom. 1064 pp.

17. Nanji, A.A., Mendenhall, C.L., and French, S.W. 1989. Beef fat prevents alcoholic liver disease in the rat. Alcohol. Clin. Exp. Res. 13:15-19.

18. 1997. Mutant mice and neuroscience: recommendations concerning genetic background. Banbury Conference on genetic background in mice. Neuron. 19:755-759.

19. Duling, D.R. 1994. Simulation on multiple isotropic spin-trap EPR spectra. J. Magn. Reson. B. 104:105-110.

20. Dignam, J.D., Lebovitz, R.M., and Roeder, R.G. 1983. Accurate transcription initiation by RNA polymerase II in a soluble extract from isolated mammalian nuclei. Nucleic Acids Res. 11:1475-1489.

21. Rusyn, I., Tsukamoto, H., and Thurman, R.G. 1998. WY-14,643 rapidly activates nuclear factor $\mathrm{\kappa B}$ in Kupffer cells before hepatocytes. Carcinogenesis. 19:1217-1222.

22. Bradford, M.M. 1976. A rapid and sensitive method for the quantitation of microgram quantities of protein utilizing the principle of protein-dye binding. Anal. Biochem. 72:248-254.

23. Zabel, U., Schreck, R., and Baeuerle, P.A. 1991. DNA binding of purified transcription factor NF- $\kappa$ B. Affinity, specificity, $\mathrm{Zn}^{2+}$ dependence, and differential half-site recognition. J. Biol. Chem. 266:252-260.

24. Baeuerle, P.A., and Baltimore, D. 1989. A 65-kappaD subunit of active NF-kappaB is required for inhibition of NF-kappaB by I kappaB. Genes Dev. 3:1689-1698

25. French, S.W., Fu, P., Li, J., Yuan, Q.-X., and French, B.A. 1999. Mechanism of the cyclic oscillation of the urinary alcohol levels in rats fed ethanol: role of the hypothalamic-pituitary thyroid axis. Hepatology. 30:337a. (Abstr.)

26. Knecht, K.T., Bradford, B.U., Mason, R.P., and Thurman, R.G. 1990. In vivo formation of a free radical metabolite of ethanol. Mol. Pharmacol. 38:26-30.
27. Burkitt, M.J., Kadiiska, M.B., Hanna, P.M., Jordan, S.J., and Mason, R.P. 1993. Electron spin resonance spin-trapping investigation into the effects of paraquat and desferrioxamine on hydroxyl radical generation during acute iron poisoning. Mol. Pharmacol. 43:257-263.

28. Bautista, A.P., and Spitzer, J.J. 1999. Role of Kupffer cells in the ethanolinduced oxidative stress in the liver. Front. Biosci. 4:D589-D595.

29. Dieter, P., Schulze-Specking, A., and Decker, K. 1986. Differential inhibition of prostaglandin and superoxide production by dexamethasome in primary cultures of rat Kupffer cells. Eur. J. Biochem. 159:451-457.

30. Pertoft, H., and Smedsrod, B. 1987. Separation and characterization of liver cells. In Cell separation: methods and selected applications. Volume 4. T.G. Pretlow II and T.P. Pretlow, editors. Academic Press. New York, New York, USA. 1-24.

31. Kono, H., Rusyn, I., Connor, H., Mason, R.P., and Thurman, R.G. 2000. Allopurinol prevents early alcohol-induced liver injury in rats. J. Pharmacol. Exp. Ther. 293:296-303.

32. Suzuki, Y.J., Forman, H.J., and Sevanian, A. 1997. Oxidants as stimulators of signal transduction. Free Radic. Biol. Med. 22:269-285.

33. Finkel, T. 1998. Oxygen radicals and signaling. Curr. Opin. Cell Biol. 10:248-253.

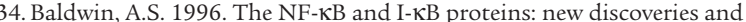
insights. Annu. Rev. Immunol. 14:649-681.

35. Nanji, A.A., et al. 1999. Activation of nuclear factor kappa B and cytokine imbalance in experimental alcoholic liver disease in the rat. Hepatology. 30:934-943.

36. Goldfeld, A.E., Doyle, C., and Maniatis, T. 1990. Human tumor necrosis factor alpha gene regulation by virus and lipopolysaccharide. Proc. Natl. Acad. Sci. USA. 87:9769-9773.

37. Iimuro, Y., Gallucci, R.M., Luster, M.I., Kono, H., and Thurman, R.G. 1997. Antibodies to tumor necrosis factor- $\alpha$ attenuate hepatic necrosis and inflammation due to chronic exposure to ethanol in the rat. Hepatology. 26:1530-1537.

38. Bevilacqua, M.P., Pober, J.S., Mendrick, D.L., Cotran, R.S., and Gimbrone, M.A. 1987. Identification of an inducible endothelial-leukocyte adhesion molecule. Proc. Natl. Acad. Sci. USA. 84:9238-9242.

39. Dustin, M.L., and Springer, T.A. 1988. Lymphocyte function-associated antigen-1 (LFA-1) interaction with intercellular adhesion molecule-1 (ICAM-1) is one of at least three mechanisms for lymphocyte adhesion to cultured endothelial cells. J. Cell Biol. 107:321-331.

40. Iimuro, Y., et al. 1997. Female rats exhibit greater susceptibility to early alcohol-induced injury than males. Am. J. Physiol. 272:G1186-G1194.

41. Feingold, K.R., Hardardottir, I., and Grunfeld, C. 1994. Cytokineinduced alterations in hepatic lipid metabolism. In Cytokines and the liver. W. Gerok, K. Decker, T. Andus, and V. Gross, editors. Kluwer Academic Publishers. Dordrecht, The Netherlands/Boston, Massachusetts, USA/London, United Kingdom. 172-181. 